\title{
The goal of Christian virtue ethics: From ontological foundation and covenant relationship to the Kingdom of God
}

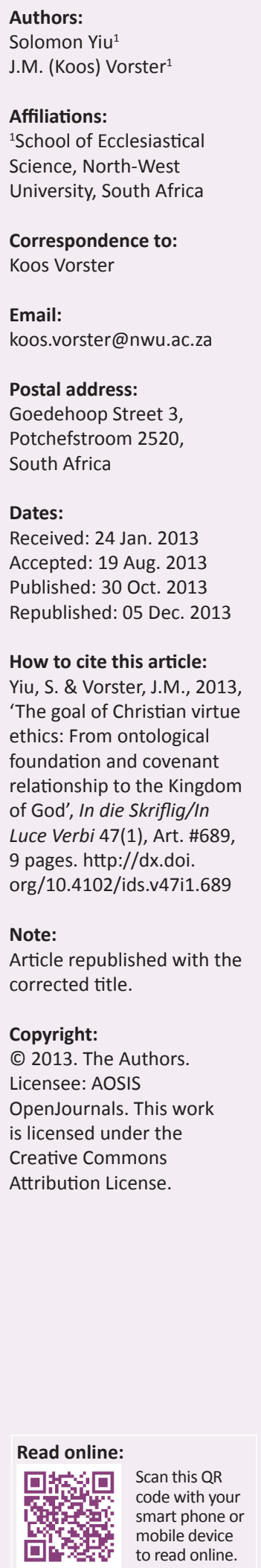

This article examined what constitutes Christian virtue ethics and its goal of highest human good. Christian virtue is a reality that is ontologically rooted in the grace of God through the atonement of Christ to envision the final good of creation. This view is drawn on the tripartite division of faith, hope and love as well as Paul Tillich's ontological focus on the acclaimed quality of the virtue of love in relation to, and unity with, the virtues of power and justice as the ultimate reality in the divine ground for human existence. Christian believers must reunite the virtues which are received from God and by which Christians transformed in reality as new beings in the pursuit of the supreme goodness. Michael Horton's covenantal model revealed a human being's encounter with God, not only meeting, but recognising a stranger (a genuine 'otherness') under a covenant that was initiated by the grace of God with an awareness of his presence that was always immanent. A covenantal approach is used to describe the divine 'presence' and 'absence' as ethical and relational in getting the right conception and direction for our purpose from God. It also deals with the question of how our moral life is related to God and fellow humans toward the final goodness which is the highest good of the Kingdom of God. This article concluded with the coming rule of God's imminent Kingdom as the true ultimate end of human beings and the eschatological fulfilment of humanity in goodness. The emphasis of the eschatological ethics lays on the theocentric futurity of the Kingdom directing Christians to the goal of the ultimate ideal and shaping the present existence of a Christian life.

Die doelwit van Christelike deugde-etiek: Van die ontologiese grondbeginsel en verbondsverhouding tot die koninkryk van God. Hierdie artikel ondersoek Christelike deugde-etiek en die doelwit van die hoogste menslike heil. Christelike deug is 'n realiteitsontologie wat veranker is in God se genade deur die versoening van Christus om sodoende die uiteindelike heil van die skepping te visualiseer. Die siening is gebaseer op die drieledige verdeling van geloof, hoop en liefde. Verder is dit gebaseer op Paul Tillich se ontologiese fokus op die prysenswaardige deug van liefde in verhouding en in eenheid met die deugde van mag en geregtigheid as die uiteindelike realiteit van die mens se bestaan. Christen-gelowiges moet die deugde wat hulle van God ontvang en waardeur hulle vernuwe word, versoen met die realiteit as nuwe wesens wat na die hoogste heil soek. Michael Horton se verbondsmodel wys dat die menslike konfrontasie met God nie net 'n ontmoeting is nie, maar ook die herkenning van 'n vreemdeling, 'n gans Andere, binne 'n verbond wat deur die genade van God geïnisieer word. Daar bly 'n bewustheid van sy teenwoordigheid wat altyd immanent is. 'n Verbondsbenadering beskryf die goddelike 'teenwoordigheid' en 'afwesigheid' as eties en relasioneel tot die verkryging van die regte verstaan van God self. Die verbondsbenadering gee ook ' $n$ begrip van hoe ons morele lewe tot God en ons medemens verbind is tot die finale heil wat uiteindelik die heil van die Koninkryk van God inhou. Die artikel sluit af met die toekomstige regering van God se immanente Koninkryk as die ware uiteinde van die mens en die eskatologiese verwesenliking van goedheid. Die klem van eskatologiese etiek lê in die teosentriese toekomsgerigtheid van die Koninkryk - wat vir Christene die rigting na die doel van die uiteindelike ideaal aandui en wat die huidige bestaan van 'n Christen bepaal.

\section{Introduction}

Christian ethicists like MacIntyre and Hauerwas, recognise the importance of what we are doing (action) and who we are becoming (being). MacIntyre's concept of 'being' is in terms of human virtue, which is 'understood as having an essential nature and essential purpose or function' to be the potentiality of a 'good human' as it exists or happens to be (MacIntyre 2007:58). Hauerwas (1975) identifies that human agent as the cause that exerts power to initiate changes and to bring something into existence, apart from external events and processes: 
Men are beings who, because they can envisage, describe, and intend their action, initiate change in themselves and the world around them in such a way that they can claim to be the cause of the change. As an agent I am not any such event, process, or state that is proposed as the 'real cause' of my act, such as some intention, motive, or state of willing [...] there is a sense in which I am an uncaused power since no other event is necessary to explain my act other than that I as an agent did it. (p. 88)

Most of the works of contemporary virtue ethicists do not aim to displace the evaluation of action with the centrality of the virtue-based evaluation of an agent, but rather to displace an artificial and incoherent account of action-based evaluation in favour of a coherent picture of act-evaluation, with strong emphasis on agent-evaluation (Foot 1978:174). It does not, however, escape the critics that this advocacy of virtue ethics fails to provide a criterion for morally correct acts and that it is problematic for the theory of virtue ethics as well as a challenger to the secular-based philosophy especially. The modern concept of a virtue is a threshold concept, as reflected in Swanton's (2003:20) definition: 'A virtue is a [...] disposition to respond to, or acknowledge, items within its field or fields in an excellent or good enough way'. The response of a human agent can take different forms or modes, dependent on the circumstances, that need not always closely approach an estimate of perfection if the agent is to exhibit virtue. Anscombe (1958:4) argues that a sound philosophy should take into account what type of characteristic a virtue is and how it relates to the actions in which it is instanced. The answer is derived in an ethical notion under the terms should, ought or needs, relating to the obligation or duty bound by relevant contexts or the divine law. This is the problem of modern philosophers who employ the concept of virtual rightness, but do not believe in any source of authority that is the ground of such assertion. Anscombe (ibid:5, 11) states that these modern philosophers who recognise the origins of the notions of 'obligation' or 'duty' in the natural law conception of ethics, do not believe in God as a lawgiver and reject the notion of a divine legislator. That is like retaining a law conception of virtue ethics without a divine legislator. Therefore, without a grounding of the divine law and an idea of a sovereign God as the supreme legislator, the concept of virtue ethics expressing overriding obligation has no place. An obedient response to the call of the sovereign God as a lawgiver and his divine law is the beginning of Christian virtue ethics.

Jesus calls us to become certain people in procession of divinely grounded virtues in order to act in a certain way as his disciples, children of God and heirs of the Kingdom. In Paul's epistles (Gl 2:20; Rm 12:1-2), Christian believers are summoned to commit as living sacrifices to a life-long journey of growth, love and service in response to the merciful love of God in Jesus Christ. A response in total obedience to God's grace in faith will lead believers, as Christian new beings, to a unique and particular realisation of God's love and an enrichment of their attitudes and dispositions. The divinely grounded virtues extolled in the Scripture which relate to all aspects of our lives, are the revealed words and instructions of God for reinforcing the divine moral character that is manifested in the Lord Jesus Christ. Keenan finds that virtue ethics can offer many resources relating to various aspects of studies of human life (Harrington \& Keenan 2002):

[They provide us with] bridges between moral theology and a variety of other fields, such as spirituality, worship, church life, and Scripture. In this way, virtue ethics unites fields of theology that have long been isolated from one another [...] In fact, the greatest bridge that virtue ethics provides is the direct connection between theologians and pastors and their communities as they try to respond to the call of Christ. (p. 25)

Every area of our lives reflects something about the kind of people we are. There is no account of virtues independent of our being and the lively application of theology. Virtue ethics does guide and connect a certain vision and conception of the good for humans. The account of the good life is not merely a disposition for action, but also leads to the pursuit of the purpose, the goal and the destiny of human life. This sounds an appeal to regain the moral good from the moral crisis in our society today. On the other hand, Aristotle (2002:103) admits the inadequacy of the virtue ethics in achieving the human goal of the higher good without gods. Wilson (1998), a contemporary Christian ethicist, also acknowledges:

However, for a Christian none of these accounts goes far enough. The Gospel reveals that the good of humanity is not found in any human institution but is given in the Kingdom of God. The conviction relativizes all other accounts of the good and brings all human loyalties under the lordship of Jesus Christ. (p. 27)

Virtue ethics that are divinely grounded by the grace of God, guide humans in the pursuit of life purpose, goal and destiny which is the Kingdom of God. Only God himself, the God of the Kingdom, is the source providing a sound foundation in reality for virtues as well as the ultimate good.

\section{An ontological foundation of Christian virtues}

The vitality of virtue ethics for our Christian living is an account of virtue ethics that is transformed by the Gospel. First of all, Christian virtues are built on the foundation of God's grace; humans must come before God with a contrite heart and recognise that only the work of the Spirit in our lives enables the Christian life (Wilson 1998). He (Wilson ibid) elaborates that:

Christian virtue directs us toward the habitual patterns of the Christian life that witness to the Gospel [...] practices directs the church toward the kind of community that embodies and forms these virtues. (p. 35)

God's grace is his loving initiative alone that constitutes the believers' particular character. For the radical consequence of the Fall, human conditions are characterised under the curse of pride, guilt and inauthenticity. Paul shows this human condition when he says: 'For what I do is not the good I want to do; no, the evil I do not want to do - this I keep on doing' (Rm 7:19, NIV). In order for the goodness of righteousness to be fully met in us, humans must not live according to the sinful nature, but let the Spirit of God work for the good of those who love him ( $\operatorname{Rm} 8: 4,28)$. Farley (1995) therefore says: 
Without God's grace, without God's forgiveness of pride and loss of self-wholeness, acts of freedom and accountability would remain bound by a darkness of the self - a darkness whose levels even of goodness would be overshadowed by the constant presence of inauthenticity. (p. 162)

Faith is a paramount virtue in response to the mystery of God's grace. Farley (1995) writes:

What a person believes and values, what he or she dares to become and be, or what communities and relationships he or she wills to support and cherish, have tremendous impact on shaping character. (p. 163)

Faith not only brings fragmented elements together in the formation of character and being, but also enlarges the self to the wholeness or the fullness of being. A transformed virtue through faith then diminishes the selfish 'self-regarding' disposition to become (Farley 1995):

[T]he person whose being is at the disposal of others and ultimately at the disposal of God [...] because such a soul knows that it is not its own [...] does not belong to itself. (p. 163)

Paul says that he no longer lives on his own, but by faith in the Son of God (Gl 2:20).

Without a commitment in faith to the reconciliation between sinners in this broken world and God, humanity could not have the character of love, discernment and trust that is proper to the people of God within the church community who already, by God's grace through faith, share in the divine life opened up to us in Jesus Christ. Dulles (1971) defends the faith associated with human virtues:

Faith $[\ldots]$ lies at the basis of all authentic virtue. Where there is not love of God, there can be no true virtue, but an authentic, supernatural love of God must rest upon faith. Thus faith is at least a pre-condition for all true virtues, including that of justice. (p. 16)

Wilson views Christian virtue ethics based on an understanding of reality very different from other virtue ethics. Christian virtue is not what humans achieve, but what God enables. It is ontologically rooted in the grace of God through the atonement of Jesus Christ to envision the final ends and the good of creation (Wilson 1998:36-37). The attainment of the goodness is solely the work of God through the Holy Spirit and not of humans. In the same context, Aquinas (1984:55) speaks of virtue as 'infused virtue' in his own theological language. He (Aquinas ibid) defines the efficient cause of infused virtue as God who works in us without us and continues to explicate his definition of infused virtue:

Infused virtue is caused in us by God without action on our part, but not without our consent. The expression 'which God works in us without us' is to be understood in that way. As to actions done by us, God causes them in us but not without action on our part, for God works in every will and nature. (p. 56)

Despite the disagreement between Protestants and Catholics about the theological concept of infusion as a permanent endowment of grace at justification, all Christians must accept that God alone is the unquestioned focal point of the existence of Christian virtues. Only through his continuing work in believers, Christians can attain the perfect goodness that God wants all believers to experience. To accept God in faith thus deepens the believer's sense of wholeness as a human being and results in a reconciled relationship with the self-revealing God who leads the Christian to become God's self-revelation in pursuit of God's highest good for the reality, presence and needs of oneself as well as one's neighbour.

By accepting God in faith, the transformation of the self is effected and the Christian believer knows that he or she now belongs to God and not to the self anymore. The life of the Christian will rest on God's purposes and begin the task of linking virtue ethics to sanctification under God's continuing guidance and gracious forgiveness. Kotva (1996:72) finds that sanctification is a process involving the continuing growth and transformation of oneself and one's character toward a partially determinate picture of the human good or end. He (Kotva ibid) summarises the theological points on sanctification as a conformity to Christ's character and likeness:

It should be readily apparent that our authors' descriptions of sanctification resemble virtue ethics at key points. Sanctification is a teleological process that involves the transformation of the self and the development of character traits or virtues. The end or goal of sanctification can be variously designated but is frequently discussed in terms of likeness or conformity to Christ. 'Conformity to Christ' thus provides a sense of sanctification's goal. (pp. 73-74)

Grenz (1997) also affirms that the conformity to Christ is the fulfilment of the purpose of our imago Dei:

The task of fulfilling our purpose as the imago Dei involves our being transformed into conformity with Christ (2 Cor. 3:18), who is the embodiment of the divine image (Col. 1:15). This entails being imbued with Jesus' own character and being motivated with the ideals that he exemplified. Thereby we become the glorified saints that God has already declared us to be. (p. 277)

\section{Faith, hope and love}

Kotva (1996) explicates a tripartite division of faith, hope and love as a sanctification process in relation to Christian virtues. He (Kotva ibid) reveals:

Faith concerns obedience to God, in conformity with Christ's own obedience, and the freedom [...] that comes with that obedience. Hope looks forward to God's continuing activity of creation and reconciliation. Love leads to community in which we help others reach their potential. (p. 73)

Farley (1995:170-173) describes the Christian virtues of faith, hope and love as instrumental in attaining the higher calling and goals of God. He begins with faith which is to accept God in the very name of the wonder and transcendence of all human experience. This faith is also instrumental to transcend the self and acknowledge the uniqueness of the self as witness to the truth and the world in order to deepen one's sense of wholeness as a human being for the divine calling that leads to profound healing and new meaning, and order for oneself and one's neighbours (Farley ibid:170-171). 
Hope supplies the sustaining power needed for perseverance and endurance to carry out a Christian moral agent's faithful commitment to moral values. Farley (1995:171) defines hope as an anticipation of the future: 'What Christian hope, based on its faith in God, is willing to risk in that the future one faces is filled with the reality, kindness, and the power of God.' The future is an anticipated ideal of human excellence and perfection. The Christian life on earth is a hope to move toward a fuller realisation of the human good, which is the Kingdom of God. Kotva (1996) adds:

Christians believe in an end beyond this life, but it only completes the renewal begun in this world. The goal after death is the consummation of a journey or process begun in repentance and continued in sanctification. (p. 76)

Hope is the ultimate goal for humans in the glorification of our God and his Kingdom involving the perfecting of human earthly life in culmination of the process of salvation.

The last of the tripartite division is love. The love of God is the motivating spirit behind God's acts and salvation. Christians bring and share love with neighbours and bear witness to the power of love as their highest moral value, because they have been loved. Farley (1995) reveals:

Love both compels the Christian to take the ethical and the universal seriously and allows the believer to be human in a way that transcends the universal and can draw one's neighbour beyond it toward the Eternal. (p. 172)

In the order of perfection, Aquinas (1984) puts charity (love) before faith and hope in that:

... both faith and hope are formed by charity and so acquire the perfection of virtue. Charity is thus the mother and root of all virtues insofar as it is the form of all virtues. (p. 123)

Paul's word in the book of Timothy is the basis of Aquinas's argument: 'The goal of this command is love' (1 Tm 1:5, NIV). Love is the motivation of all virtues in that it commands the activities of all other virtues as the higher power toward the goal of the higher good or perfection (Aquinas 1948:II-II, A8, Q23).

Aquinas values love or charity as the mother and root of all virtues in the order of higher perfection by linking and working cohesively with other virtues such as faith and hope as well as justice. The theme of love is enjoined throughout the Bible. Jesus' summary that it is imperative to love God and one's neighbour, is the greatest commandment. This is the Christian tradition known as 'the core and climax of the whole of moral doctrine' (Grenz 1997:278).

The Bible focuses on love as an acclaimed quality that Christians pursue in the theological and ethical meaning of the concept of the character of God. Love is central, because it is the foundational principle and primary context for living as believers. Tillich (1963) describes love as the higher principle and actual unity of life in his book titled Morality and Beyond:

I have given no definition of love. This is impossible because there is no higher principle by which it can be defined. It is life itself in its actual unity. The forms and structures in which love embodies itself are the forms and structures in which life is possible, in which life overcomes its self-destructive forces. And this is the meaning of ethics: the expression of the ways in which love embodies itself, and life is maintained and saved. (pp. 94-95)

\section{Love, power and justice}

In a little book titled Love, Power, and Justice, Tillich conducts another study on the virtue of love by adopting an ontological analysis to describe love in relation to and unity with the virtues of power and justice. Ontology, for Tillich, is the foundation of metaphysics, but not metaphysics itself. It asks the question of being and encounters the reality to reveal the universal structural elements participating in being as well as the qualities of being (Tillich 1960:23). Kirkpatrick (2003) consents with this presupposition: 'Without asserting some metaphysical theory that accounts for God's ontological reality, theistic ethics cannot get off the ground.' $\mathrm{He}$ (Kirkpatrick ibid) expounds further:

$[H]$ owever, the grounding of this metaphysics need not entail the traditional or classical notions of God as non-temporal, impassable, unable to act in history, and ontologically transcendent of all that is finite and historical. (p. 5)

The ontological character of love begins with life. As Tillich (1960:25) reasons, life is being in actuality, whilst love is the moving power of life, but this being is not actuality without the love to unite everything to everything. Love drives the unity of the estranged towards an ultimate belongingness in self-fulfilment.

Power is a potentiality that exists or is actualised only in a being's encounter with the other as a form of self-affirmation dynamics in overcoming internal and external resistance or non-being (Tillich 1960:35-41). This power of being, as Tillich calls it, is to shape the self in its self-centredness by a stabilised balance against disruptive tendencies and a union of all constitutive elements (love and justice included) without the exclusion of most of them (Tillich ibid:52).

Justice is an adequate form in which the power of being actualises itself under the principle of love, in order to encounter all essential elements of personal existence, such as adequacy, equality, human rather than thing, and liberty (Tillich 1960:56-62). Tillich (ibid) stresses that justice preserves what love reunites, but love is the ultimate principle of justice:

Love does not do more than justice demands, but love is the ultimate principle of justice. Love reunites; justice preserves what is to be united. It is the form in which and through which love performs its work. Justice in its ultimate meaning is creative justice, and creative justice is the form of reuniting love. (p. 71)

Tillich leads us to realise the unity of love, power and justice as the ultimate reality in the divine ground for human existence. God is the subject of all symbolic statements in human concerns of love, power and justice. The symbolic in relation to God is the only true way of speaking about God - the One with whom we have a person-to-person encounter and whose life infinitely transcends our life in 
being and meaning (Tillich 1960:109-110). Tillich (ibid:111) concludes that 'to see love, power and justice as true symbols of the divine life, means to see their ultimate unity'. The importance of the unity and the proper application of love, power and justice is that it provides a system of checks and balances to ensure harmonious personal, group and divine relations. Love, power and justice are rooted in the divine life, the highest being which is the ultimate unity (Tillich ibid:110-111). To preserve human life in unambiguous good, humankind must reunite as one in terms of love, power and justice which humankind receives from God who transcends and affirms them. Love, power and justice are united in God and they are united in the new creation of God in the world (Tillich ibid:115).

God is his own self-existent ethical principle of virtues. His being is unitary. He is not composed of a number of parts working harmoniously, but is simply one. His goodness flowing out of his love is not goodness if it is without justice and power. The same applies to justice without love and power or power without love and justice. Since the God of love is also just and powerful God, the virtues of love, power and justice cannot stand juxtaposed. Love may go beyond justice with power, but it can never seek less than justice and become powerless. All these virtues of love, power and justice must serve each other in order to achieve the human ends.

\section{Summary}

In conclusion, Christian virtue ethics is ontologically grounded in God who is the source of all virtues. It is God himself, pouring and producing in us the divine gifts of virtues through the merits of Christ. The works of God transcends our natural capacities into the tripartite division of faith, hope and love. Faith makes us know our God to whom we are obediently and faithfully living for; hope makes us look forward to consistently and ultimately joining him in the final destiny; and love leads us to love him and our neighbours. Christian believers are new creations of God through faith and hope and must thus reunite all the virtues of love, power and justice received from God and live in ontological reality as new beings in Christ. These Christian virtues are the qualities of the life of the new beings who answer the call of Jesus and fulfil their functions as followers of Christ in the pursuit of the true goodness and ultimate finality.

\section{A covenantal model of Christian virtue ethics}

The ontological conception of God as an infinite being, as a standard of righteousness or as a source of virtues, seems to embrace an idea of transcendence in which the reality of God is hardly affirmed or denied. Tillich (1959) does not consider his ontological view of God as an approach of avoiding a stranger, but an innermost unity with God in an intimate relationship:
In the first way ['overcoming estrangement' or the 'ontological' view] man discovers himself when he discovers God; he discovers something that is identical with himself although it transcends him infinitely, something from which he is estranged, but from which he never has been and never can be separated. (p. 10)

Human souls are not strangers to God, but have a continuing knowledge of God. To encounter him is like not only meeting, but also recognising a stranger (a genuine 'otherness') with an awareness of his presence that is always immanent. From the revelation he gives them of himself in his activities, humans form their knowledge of God a posteriori rather than a priori (Horton 2004:344). God communicates directly and he primarily communicates the attributes of his goods (not simply his being) to creatures. Therefore, Horton (ibid:345) suggests that ' $[t]$ he covenant is the place where a stranger meets us' as an ethical clearing - not as a preoccupation with 'being' or 'essence', but to know 'what it was like for God to be'. Horton (ibid:347) indicates that 'one implication of a covenantal approach is that divine "presence" and "absence" are ethical and relational rather than ontological categories'. The importance of our Christian theology lies not simply in getting the right conception of God for our purpose, but in calling on the actual presence of God who is there and has made himself available to us. Where can we find God's gracious presence? Horton (ibid:354) answers: 'The covenant of grace is the place and the Son is the mediator of this saving encounter.' The biblical faith affirms the life of believers meeting a Stranger (at the covenantal place) in an ethical sense rather than a metaphysical problem.

Covenant is a central theme throughout the Bible - from Abraham, Noah and Moses, to David. The covenant is profoundly important in both Testaments and sheds considerable light on a biblical understanding of God's will and action upon the existence of Christian moral life. Such a model of Christian moral life has to do with the question of how our moral life is related to God and our fellow humans. This ethical position or relationship is rooted in the Christian confession that Jesus Christ is the Lord of faithful believers who belong to the same moral community in their own rights by participating and accepting their mutual entrusting and enduring responsibility to all others (Allen 1984:17). The Christian confession followed by the obedience of believers results in the forgiveness of their sins and immoral acts out of love from God. This forgiveness of God covers believers' whole life - both earthly (ethical) and eternal (heavenly), and in all dimensions. It brings believers to a unified response to a very deep love and full obedience to God's covenant.

\section{Definition of a covenant}

Allen (1984:32) recognises that the term covenant can refer to both the characteristics of a certain type of interpersonal relationship or simply the relationship itself, but he prefers to adopt the use of the latter sense. He defines a covenant as:

1. A relationship that comes about through interactions of entrusting and accepting entrustment amongst willing, personal beings. 
2. As a result, the parties belong to the same moral community and have responsibility to and for one another as beings who matter.

3. Their responsibility in the relationship endures over time.

A relationship under a covenant does not come into being by biological or geographical designation, but by an acceptance of one another's entrustment. It always involves some moral actions corresponding to their responsibility under the entrustment relationship. Allen's (1984:15) definition summarises his own view of a relational covenantal model: 'A model of the moral life has to do with how moral selves are related, and not merely nor primarily how they ought to be related.' It is the character of responses in moral actions from selves to selves in their physical and social context.

\section{Covenantal community}

No one can avoid this physical and social context in any kind of relationship (covenant or social contract) when sharing a particular kind of life with others. Kirkpatrick (2003) reaffirms:

And that context, whether it be that of a purely self-interested contractual arrangement with other persons, a church, or a family, will necessarily create the conditions for and point persons toward a particular kind of life. (p. 154)

The church, as a religious and covenantal community, is the necessary basis and special place for the development of the full person of virtue by responding in a faithful way to the will and action of God. The truth of particular Christian virtues, developed through God's human community, is proven in the practice of human life toward the flourishing of persons in relation to God and others. Kirkpatrick (2003) concludes:

[T] he biblical theist's moral ontology holds that these virtues are essential parts of the full and true life and that they are part of God's intention for God's human community. (p. 154)

\section{The biblical covenant}

The Christian covenant is a relationship initiated and made by the God of grace. Unlike the social contract - the humanto-human covenant that is only a relationship of bargaining and laying out the terms of rights and obligations - each covenant initiated by God (in both Testaments) is set by God and is not negotiable. This is God's own covenant. Therefore, God repeatedly stated 'my covenant' in the Old Testament. The terms of each covenant are the reflection of God's power and grace in the creation of a new thing or covenant community that accepts and receives his gracious promises and benefits. God's will is thus made known in the covenant relationship with his people. To fulfil the will of God in the covenant, the people of God must exercise their faithful obedience with the love of God (Ps 103:17-18).

The focus of the biblical covenant is a person-in-relationship following the vision of the social Trinity - the Trinitarian persons in eternal fellowship (Grenz 1997:277). In this social
Trinity, the Father initiates the covenant, the Son mediates it and the Spirit acts for it. The work of each person of God can be seen as a unity of the God of love and as an example to humankind of the character and nature of this love. The task of fulfilling Christian purpose in the covenant is to enter into the fellowship of Christ's community, the church, through transformation by the Holy Spirit. Hence, the people of God are designated to reflect the social Trinity and conform to God's loving character in Christians' relational ethical life toward others (Grenz ibid:278).

In addition, the biblical covenant has an eschatological implication, which is to reflect God's eternal glory in Christians' good deeds in doing his will:

May the God of peace, who through the blood of the eternal covenant brought back from the dead our Lord Jesus, that great Shepherd of the sheep, equip you with everything good for doing His will, and may He work in us what is pleasing to Him, through Jesus Christ, to whom be glory for every and ever. Amen. (Heb 13:20-21, NIV)

For the covenant people of God, the final human goal in doing God's will is to become the very dwelling place of God, as promised:

Then I saw a new heaven and a new earth [...] I saw the Holy City, the New Jerusalem, coming down out of heaven from God [...] And I heard a loud voice from the throne saying, 'Now the dwelling of God is with men, and he will live with them. They will be His people, and God Himself will be with them and be their God. He will wipe every tear from their eyes. There will be no more death or mourning or crying or pain, for the old order of things has passed away.' (Rv 21:1-4, NIV)

The people of the covenant thereby have this gracious promise and an enduring responsibility for their lives to God and one another throughout the life of the eternal covenant on earth as well as the dwelling place in the heavens.

The concept of inclusiveness and exclusiveness of the people of God under covenant, reflects the God who wills and acts in justice. The blessing for all nations is a reality in Abraham's blessing. The church today must comply obediently with God's righteous mandate and, as faithful servants of Christ, must witness the reality and efficacy of the work of Jesus Christ, who assembles his eternal Kingdom from all nations. God intends for all human creatures to be included in the covenant, whether they consciously affirm it now or not. Jesus' double love commandment tells the meaning of agape [love] as the requirement for faithfulness to God and to all persons without any exclusive qualification. Faithfulness in love or 'entrustment' in Allen's terminology, is a proper requirement of every human relationship and situation on an inclusive basis. Allen (1984) discloses:

Although we can distinguish between the inclusive covenant and special [exclusive] covenants, we cannot separate them. We are always in both at once, and ordinarily in several types of special covenants at once. (p. 45)

After all, God is the centre of the moral life of all humankind and, as such, he will bring his people under the exclusive or special covenant to foster the true fulfilment of the 
common good of the community for the moral unity of all people under God.

\section{Losing our virtue}

In his book titled Losing our virtue, Wells charges that there is no effective Christian presence in society - especially not in the evangelical church which today has little appetite for speaking about the crisis of character in the face of the disintegrating moral culture in America (Wells 1998:1-2). Despite the growth in number and size of the evangelical churches in recent years, Wells (ibid) finds the following:

[There is] a loss of the biblical Word in its authoritative function, and an erosion of character to the point that today, no discernible ethical differences are evident in behaviour when those claiming to have been reborn and secularists are compared [...] now that they have become large in number they have been diminished in stature. (p. 3)

Wells (1998:7) cites ancient Rome as a case study of cultural collapse in general. Rome's collapse was not due to Christian morality, but rather pagan immorality. But the question with regard to what Christians did to relay the providence of the justice of God and extend the relation of Christ and culture besides renouncing the world and disengaging from society - remain. We must understand that God's Kingdom of peace and justice is not merely a remote ideal for which we long. Dulles (1971) discloses that:

In Jesus Christ the Kingdom of God has entered into history. It is already at work, albeit only germinally transforming the world in which we live. Faith is the Christian's mode of participation in that Kingdom. Insofar as we have faith, the Kingdom takes hold of us and operates in us. This means that through faith we become instruments in the healing and reconciliation of the broken world. We become agents of justice and bearers of the power of the Kingdom. (p. 43)

\section{The Kingdom of God as the highest good of human goal \\ Aristotle}

Aristotle begins his teleological virtue ethics with the end (goal or telos). It is true that the goal always defines and shapes the agenda being pursued by human moral agents. Keenan agrees with this argument by saying that 'the agenda from start to finish, is shaped by the end' (Harrington \& Keenan 2002:40). For Aristotle, happiness (goodness or flourishing) is the human end in cultivating the virtues and avoiding the vices at their extremes in order to aim for a life with the greatest possible end. However, Pannenberg (1975:106) criticises the inadequacy of human happiness as the end: 'Eudaemonism does not recognize that ethical action is performed for the sake of the good regardless of the consequences for the acting person.' It is simply that happiness cannot prove the presence of 'good', as evil persons can find happiness in their bad and evil acts. Aristotle's idea of flourishing (eudaimonia) does not provide a standard that successfully distinguishes virtue from vice, as he is never specific about what is contemplated as intrinsically valuable (Conly 1988:84, 87).
Nussbaum (1992:214) partly agrees with this argument in accepting that the Aristotelian conception of human end in happiness (goodness or flourishing) is the thick vague of the good. Nussbaum (ibid:215) tries to defend Aristotle's position as a deliberation to leave it vague in good sense, rather than precisely wrong, and justifies it as a generally shared consensus amongst humankind. Her defence, however, leaves the question of the goal of human end unanswered and is without a clear certainty of what 'good' is. Nussbaum later shifts her position from Aristotelianism to political liberalism with a focus on human capacities and autonomy. Her new position in pluralism and human freedom moves her further away from any moral norm of human good, but accepts a life of free choices to be made based on various structures of one's affiliation and group-based relationships (Nussbaum 2011:40). In one word, a life that is freely chosen by humans' deliberated and practical decisions becomes the human good itself. Modern moral philosophy becomes part of the problem because of its stress on autonomy and the corresponding attempt to free ethics from norms, and thus produces people incapable of living lives that have narrative coherence. What is then the true ultimate end of human beings?

\section{Aquinas}

Aquinas (1948:I-II, Q1, A1, 4, 6) agrees that human beings always act for an end, but argues that the true ultimate end of human beings happens solely in communion with God, which is in effect the Kingdom of God where human beings find happiness. No secular or human-made happiness, like Aristotelian eudaimonist virtue ethics, can ever substitute for the perfect happiness that God wants all believers to experience in a life and relationship under the law and rule explicitly structured by him. This communion with God is about knowing his being and existence which cannot be conceived apart from his rule (the Kingdom of God) as well as the knowledge of ourselves, our vulnerability, our sinfulness and our limitations. God has the power to rule as the highest spiritual being and to identify himself as the ultimate good of the ethical quest relating to human beings and their world. His rule, in an important sense, is therefore coming into existence - not only for the highest good of human future, but also into existing present reality. Bavinck (2011) explains clearly why the Kingdom of God is the highest good encompassing all goods:

The Kingdom of God as the highest good for humanity is indeed a Kingdom that in its essence surpasses everything temporal and earthly. This in no way means, however, that the Kingdom of God therefore exists in enmity against everything temporal and earthly, but much rather need them as its instrument and is prepared to be an instrument for their sakes. (p. 140)

\section{The Bible}

The Kingdom of God is the central theme of Jesus' preaching and the theological context for his healing. It is also the horizon of his ethical teaching in many parables, for example in Mark 4, Matthew 13, 24 and 25 as well as in Luke 8. The 
definition of what is good and what is right must include reference to the coupling of the Kingdom of God and agape [love] in the person of Jesus Christ. Braaten (1974:116) affirms that it is the highest good in ethics, because God promises the coming of his Kingdom as the eschatological fulfilment of humanity in goodness. The Kingdom of God in its fullness and perfection is no product of human striving, but is subject to the rule of God through a positive and faithful communion with God. In the eschatological ethics, the emphasis lies on the theocentric futurity of the Kingdom with a present impact in the person of Jesus and the presence of the power of his Word to this world (Braaten ibid:117). It is the ultimate fulfilment of a divine purpose and the manifestation in the end of days of the final and complete mystery of the divine will. The thrust of devotion is not from natural to supernatural or from human to divine, but in reaching out to welcome the future of God's promise (Pannenberg 1975:40). The cooperation of human beings in devotion to the divine will and purpose by the operation of the Spirit, is being worked out in the course of world history to the goal in the revelation of the New Jerusalem which is from above.

Being in communion with God is the dynamic of Christian devotion that Christians are longing for - the will and purpose of God for their life in the present and the future. This devotion in piety is not an amorphous longing, but is in communion with the specific event which is clearly the future coming of the Lord Jesus Christ. In communion with Jesus, a communion that is in cooperation with his continuing ministry to the world, we have a foretaste of the ultimate fulfilment. Thus, the Kingdom of God does not simply provide a motivation for an eschatological hope, but also gives shape to the contents of Christian ethics with a defining end (Harrington \& Keenan 2002:43).

The goal of a Christian life is the ideal of the Divine Kingdom, and the end of all human existence should also be the Kingdom. Grisez (2008) suggests an encompassing interpretation of the ideal of the Divine Kingdom for human or Christian end, rather than a narrow sense of a personal or individual goal:

That end is integral communal fulfilment in God's Kingdom, which will be a marvellous communion of divine Persons, human persons, and other created persons. Every human member of the Kingdom will be richly fulfilled not only in attaining God by the beatific vision but in respect to all the fundamental human goods. (pp. 58-59)

For those who take the Kingdom of God as their ultimate end, the goal is not only to attain the ultimate proper good in their unique ways, but to participate in the 'integral communal fulfilment' (a term coined by Grisez 2008:57) to realise the ultimate end in the Kingdom for all created persons as a whole. It is God's plan for the fullness of time to unite all things in Christ, God himself:

And He made known to us the mystery of His will according to His good pleasure, which He purposed in Christ, to be put into effect when the times will have reached their fulfilment - to bring all things in heaven and on earth together under one head, even Christ. (Eph 1:9-10, NIV)
For He 'has put everything under his feet'. Now when it says that 'everything' has been put under Him, it is clear that this does not include God Himself, who put everything under Christ. When He has done this, then the Son Himself will be made subject to Him who put everything under Him, so that God may be all in all (1 Cor 15:27-28, NIV)

The Lord has established His throne in heaven, and His Kingdom rules over all (Ps 103:19, NIV).

\section{The role of the church}

The foundation of the doctrine of the church builds on the Kingdom that 'must be the central concern of the church if the church is to remain faithful to the message of Jesus' (Pannenberg 1975:73). Since the Kingdom of God is the integral communal fulfilment to realise the ultimate end of the world, the church must presuppose some other larger community beyond the Christian community and justify itself in terms of its relation and responsibility to the world. Nevertheless, the church is not the Kingdom of God or the present reality of God's Kingdom. The church must faithfully follow Jesus' pointing toward the Kingdom of God and fulfil its vocation to be the transforming agent of the world whilst submitting to God's manifestation and rule. Through the witness of the church as a representation of the Lord Jesus in the world, the Kingdom of God will bring ultimate justice - the fulfilment of a unified orderly human social life willed by God.

In addition, the church has a vital role in bringing the universal idea of justice and love and care for one another in the world. This is an eschatological ethic of love, power and justice, brought under the conditions of a sinful world that has not yet been apocalyptically transformed into the new world of God's future (Braaten 1974:117). The concept of this eschatological ethics not only translates the dynamics of love, power and justice operative in this given world, but also injects God's norms of the future into the contexts of the present. Braaten (ibid:122) concludes: 'This determines the goal of ethics - the Kingdom of God as the highest good.'

\section{Conclusion}

The life of the Christian rests on God's purpose. It begins with the task of linking the virtue ethics of faith, hope and love as instruments in attaining wholeness as a human being. This wholesness of a Christian life is a fuller realisation of human excellence in the Kingdom of God and the motivating spirit behind God's acts of salvation in order to draw one's neighbour toward the Eternal. Tillich (1960:115) realises that God is his own self-existent principle of virtue ethics (love, justice and power) which Christians receive from God as new beings in Christ in the pursuit of supreme goodness. Christians must not only recognise God's being as 'otherness', but must also encounter him with an awareness of his presence which is always immanent under a covenant relationship that requires responsibility and faithfulness to the will and action of God. In both Testaments, this covenant relationship is initiated by God as absolute and is unlike the social contracts of philosophical theories which are human- 
to-human covenants subject to bargaining and the laying out of the terms of rights and obligations. The church is a religious and covenantal community working towards the development of the full person of virtue, and pursuing the final human goal according to God's supreme power and rule relating to the ultimate good for humanity. God himself is this ultimate good or end which is the Kingdom of God. The final human goal in doing God's will, his ultimate good, is to become the promised dwelling place of God ( $\operatorname{Rv} 21: 1-4)$. Human happiness (goodness or flourishing) is the greatest possible human end in cultivating the virtues and avoiding the vices. Pannenberg (1975:106) argues the inadequacy of human happiness as the end, simply because this happiness does not prove the presence of the good when evil persons can also find happiness in their evil acts. Only the Kingdom of God, the presence of the power and rule of God and his Word can bring the fullness and perfection of happiness. It is not a product of human striving, but a faithful devotion to the will of God. The goal of a Christian life on earth and of all human existence is the ideal of the Divine Kingdom. This is not merely an eschatological hope for the future - it is also that which gives shape to the Christian life and Christian ethics in the present.

\section{Acknowledgements Competing Interests}

Authors of this article declares that they have no financial or personal relationship(s) which may have inappropriately influenced them in writing this article.

\section{Authors' Contributions}

Both J.M.V. (North-West University) and S.Y. (North-West University) contributed to this article. S.Y. was responsible for identifying important sources, giving experiental inputs and revising the final product, whilst J.M.V. was responsible for the final editing and finishing touches on the article.

\section{References}

Allen, J.L., 1984, Love \& conflict: A covenantal model of Christian ethics, Abingdon Press, Nashville.
Anscombe, G.E.M., 1958, 'Modern moral philosophy', Philosophy 33(124), 1-16. http://dx.doi.org/10.1017/S0031819100037943

Aquinas, T., 1948, St. Thomas Aquinas' Summa Theological, vol. I-V, transl. Fathers of the English Dominican Province, Christian Classic, Notre Dame.

Aquinas, T., 1984, Treatise on the virtues, transl. J.A. Oesterle, University of Notre Dame Press, Notre Dame.

Aristotle, 2002, Aristotle Nicomachean Ethics, transl. C. Rower, comm. S. Broadie, Oxford University Press, Oxford.

Bavinck, H., 2011, 'The kingdom of God. The highest good', transl. N.D. Kloosterman, The Bavinck Review 2, 133-170.

Braaten, C.E., 1974, Eschatology and ethics: Essays on the theology and ethics of the kingdom of God, Augsbury Publishing House, Minneapolis. PMCid:PMC333086

Conly, S., 1988, 'Flourishing and the failure of the ethics of virtue', Midwest Studies in Philosophy 13(1), 83-96. http://dx.doi.org/10.1111/j.1475-4975.1988.tb00114.x

Dulles, A., 1971, 'The meaning of faith considered in relationship to justice', in J.C. Haughey (ed.), The faith that does justice: Examining the Christian sources for social change, pp. 10-46, Paulist Press, New York.

Farley, B.W., 1995, In praise of virtue: An exploration of the biblical virtue in a Christian context, William B. Eerdmans Publishing Company, Grand Rapid.

Foot, P., 1978, Virtues and vices, Oxford University Press, Oxford.

Grenz, S.J., 1997, The moral quest: Foundations of Christian ethics, InterVarsity Press, Downers Grove.

Grisez, G., 2008, 'The true ultimate end of human beings: The kingdom, not God alone', Theological Studies 69(1), 38-61.

Harrington, D.J. \& Keenan, J.F., 2002, Jesus and virtue ethics: Building bridges between New Testament studies and moral theology, Sheed \& Ward, Lanham.

Hauerwas, S., 1975, Character and the Christian life: a study in theological thics, Trinity University Press, San Antonio.

Horton, M.S., 2004, 'Meeting a stranger: A covenantal epistemology', Westminster Theological Journal 66(2), 337-355.

Kirkpatrick, F.G., 2003, A moral ontology for a theistic ethic: Getting the nations in love and justice, Ashgate Publishing, Aldershot.

Kotva, J.J., 1996, The Christian case for virtue ethics, Georgetown University Press, Washington, DC.

Maclntyre, A., 2007, After virtue: A study of moral theory, University of Notre Dame Press, Notre Dame.

Nussbaum, M.C., 1992, 'Human functioning and social justice: In defense of Aristoteliam essentialism', Political Theory 20(2), 202-246. http://dx.doi. org/10.1177/0090591792020002002

Nussbaum, M.C., 2011, Creating capabilities: The human development approach, Belknap Press, Cambridge, MA. http://dx.doi.org/10.4159/ harvard.9780674061200

Pannenberg, W., 1975, Theology and the kingdom of God, The Westminster Press, Philadelphia.

Swanton, C., 2003, Virtue ethics: A pluralistic view, Oxford University Press, New York. http://dx.doi.org/10.1093/0199253889.001.0001, PMCid:PMC162152

Tillich, P., 1959, Theology of culture, in ed. R. Kimball, Oxford University Press, New York.

Tillich, P., 1960, Love, power, and justice: Ontological analysis and ethical application, Oxford University Press, London.

Tillich, P., 1963, Morality and beyond, Harper \& Row, New York.

Wells, D.F., 1998, Losing our virtue: Why the church must recover its moral vision, William B. Eerdmans Publishing Company, Grand Rapids.

Wilson, J.R., 1998, Gospel virtue: Practicing faith, hope \& love in uncertain times, InterVarsity Press, Downers Grove. 